\title{
Ways of the lead-bearing slag waste utilization
}

\author{
Gaukhar Zahievna Turebekova ${ }^{1}$, Saule Ospandiyarovna Akhmetova, ${ }^{2, *}$, and Zarina Ilesovna \\ Bagova $^{1}$ \\ ${ }^{1}$ M.Auezov South Kazakhstan University, Shymkent, Republic of Kazakhstan \\ ${ }^{2}$ Almaty Technological University, Almaty, Republic of Kazakhstan
}

\begin{abstract}
The article presents the results of research on the influence of lead production slag on the environment and ecology of the city. Due to the open storage of slags, an excess of maximum permissible levels (MPL) of lead was established: near the plant, the concentration of lead in the soil exceeds $3000 \mathrm{mg} / \mathrm{kg}$, while the MPL is $3.2 \mathrm{mg} / \mathrm{kg}$. The data of analyzes obtained by methods of scanning electron microscopy and X-ray microanalysis, performed on a scanning electron microscope (SEM), as well as the results of X-ray fluorescence semi-quantitative analysis, performed on an X-ray fluorescence wave-dispersive spectrometer, have been presented. The results of thermal analysis of samples in air in the 20$1000{ }^{\circ} \mathrm{C}$ temperature range are presented.It was revealed that lead slag contains a fairly high amount of toxic metal compounds. It has been established that the average content of toxic metals in slags formed as a result of the activity of a lead plant is: lead - 2, 38\%; zinc - 9.81\%; copper $0.97 \%$; iron - $25.31 \%$; silicon oxide - $24.62 \%$; calcium oxide $16.21 \%$; potassium oxide $-1.42 \%$; sulfur $-1.35 \%$ of the total sample weight.The offered technology of a selective method for the extraction of non-ferrous metals allows to enhance the ecological state of the environment and reduce their negative impact on human health by means of the disposal of the lead production slags.
\end{abstract}

\section{Introduction}

As a result of the activities of the Shymkent Lead Plant, about 2 million tons of man-made waste in the form of lead-containing slags have accumulated. Lead production slags contain a large amount of toxic compounds of heavy metals such as lead, zinc and cadmium, which are the dangerous environmental pollution sources [1-4].

Even after the closure of the plant, the remaining waste in the form of slag is a source of environmental pollution of soil, groundwater and air. The environmental expertise revealed a huge excess of the maximum permissible concentration (MPC) of lead in the soil near the former lead plant: currently, at the site of the plant and near the concentration of lead is more than $3000 \mathrm{mg} / \mathrm{kg}$ in the soil with the MPC $3.2 \mathrm{mg} / \mathrm{kg}$ due to open storage of slags, which cause irreparable damage to the vitals of living organisms and the health of the population of nearby areas (densely populated microdistricts of Shymkent Kazygurt,

\footnotetext{
${ }^{*}$ Corresponding author: sunrise_kz@mail.ru
} 
Sauleand other nearby streets of the Abaysky district), as well as hinder the labor safety and industrial sanitation to various business facilities located in this area [5-7].

Lead and zinc compounds are dangerous to a human due to their significant toxicity and ability to accumulate in the body. Lead poisoning ranks first among the professional intoxication of workers in the field of production. For instance, wastewater containing zinc compounds is not suitable for irrigation of fields, the negative effect of zinc compounds on microorganisms and soil microfauna reduces soil fertility, although zinc plays a certain role in plant metabolism. Pursuant to research data and analyzes of the content of lead compounds in plants growing near slag storage, an excess of the MPL from 1.83 to 8.13 times was recorded [8-10]. The environmental damage caused by the long-term storage of slag is seriously dangerous when the slag is in an acidic environment (soil $\mathrm{pH}<4$ ). Contamination of the soil of Shymkent with compounds of lead and other metals contained in waste slags causes the ingress of harmful chemical compounds into the human body. Lead compounds impact the human nervous system, cause the decrease in intelligence, changes in physical activity, coordination of hearing, impact the cardiovascular system and have a significant impact on life safety [11]. Lead intoxication ranks first among the professional intoxications, and there is a tendency to its increase. About $40 \%$ of workers affected by lead exposure are women. Lead is especially dangerous for the breastfeeding women, because it has the ability to cross the placenta and accumulate in breast milk. Unfavorable meteorological conditions during this period of the year also contribute to the accumulation of lead in the lower atmosphere layers. Lead enters the body through the gastrointestinal tract and respiratory system, and then spreads through the blood throughout the body. Herewith, the danger of the lead dust inhalation is much more dangerous than the presence of lead in food. Lead compounds also accumulate in bones, partially replacing calcium in phosphate. Getting into human soft tissues - muscles, liver, kidneys, brain and lymph nodes [12], the lead causes a disease called plumbism. Like many other heavy metals, lead (in the form of ions) blocks the activity of certain enzymes. The activity of enzymes decreases 100 times with an increase in the concentration of lead in the blood 10 times - from 10 to 100 micrograms per $100 \mathrm{ml}$ of blood. At the same time, anemia develops, the hematopoietic system, kidneys and brain are affected, and intelligence decreases. This impacts the health of the population and especially children, who are most susceptible to lead poisoning. Lead can easily enter the body with drinking water if it comes into contact with metal: in the presence of carbon dioxide, soluble bicarbonate slowly passes into the solution. It is enough that there is only one milligram of lead in one liter of water, and drinking such water becomes very dangerous. Most often, lead comes from the atmosphere into the soil in the form of oxides, where it gradually dissolves, passing into hydroxides, carbonates, or another form of cations [13]. Food is the main source from which lead enters the human body. In addition to this, the important role is played by the inhaled air plays, as well as the lead dust that children ingest. About $30-50 \%$ of the inhaled dust is retained in the lungs, and a significant proportion of it is absorbed by the blood. Absorption in the gastrointestinal tract of the adults is $5-10 \%$, with up to $50 \%$ in case of children. Deficiency of calcium and vitamin D increases the gastrointestinal tract lead absorption rate. On average, the human body absorbs $26-42 \mu \mathrm{g}$ of lead per day. About $90 \%$ of the total amount of lead in the human body is found in bones, with $60-70 \%$ in case of children [14]. In addition to lead, the lead slag contains zinc compounds able to significantly impact the life safety and the environment. Wastewater containing zinc is not suitable for irrigation of fields, therefore, the increased content of zinc impacts the microorganisms and microfauna of the soil, significantly reducing its fertility. Many manifestations of zinc intoxication are based on the competitive relationship of zinc with a number of other metals. For instance, residents of nearby areas showed a significant decrease in the total level of calcium in the blood serum. Excessive intake of zinc into the 
body was accompanied by a drop in the calcium content not only in the blood, but also in the bones, at the same time the absorption of phosphorus was impaired; as a result, osteoporosis developed. The toxicity of zinc oxide is explained by its catalytic activity, which poses a mutagenic and oncogenic hazard, disrupting the human life safety [15]. Thus, due to the great harm to the health of the population of the neighboring regions of Shymkent, the problem of disposal of lead production slags is very acute and relevant.

\section{Materials and methods}

The study of the material composition was performed on bulk slag material, externally black, with a particle size ranging within 2-6 mm. In the course of the study, a heavy fraction was isolated from the sample, from which polished artificial polished sections (briquettes) were made. The polished sections were analyzed under a LEICA DM 2500P microscope. In addition, the sample was examined under a microscope in immersion liquids, as a result of which samples were taken for further research.

Scanning electron microscopy of the slag was performed on a JEOL-6490 LV microscope (JEOL, Japan) in order to measure the scale factor of the video image by obtaining the surface of an object with a high spatial resolution, as well as elemental analysis and elemental mapping at low magnifications.

The X-ray fluorescence semi-quantitative analysis of the slag was studied on an Axios X-ray fluorescence wave-dispersive spectrometer (PANalytical BV, Netherlands), and the determination of the elemental composition of the substance was performed by the X-ray fluorescence analysis (XRF) method.

In addition, a differential thermal analysis of slag samples was performed on a Q1000/D derivatograph, system of F. Paulik, J. Paulik and L. Erdey provided by "MOM" (Hungary, Budapest). The survey was performed in air, in the temperature range of 20-1000 ${ }^{\circ} \mathrm{C}(293-1273 \mathrm{~K})$, the heating mode was dynamic $(\mathrm{dT} / \mathrm{dt}=10)$, the reference substance was calcined $\mathrm{Al}_{2} \mathrm{O}_{3}$, the sample weight was $500 \mathrm{mg}$ with a scale division of the sample weight $500 \mu \mathrm{V}$. The studies were performed with the following parameters: the sensitivity of the balance is $100 \mathrm{mg}$, the sensitivity of the other measuring systems of the device: DTA $=250$ $\mu \mathrm{V}, \mathrm{DTG}=500 \mu \mathrm{V}, \mathrm{TG}=500 \mu \mathrm{V} \mathrm{T}=500 \mu \mathrm{V}$. The applied method is based on recording changes in the thermochemical and physical parameters of a substance that can be caused during its heating. The thermochemical state of the sample is described by the corresponding curves: temperature (T), differential thermoanalytical (DTA), thermogravimetric TG and differential thermogravimetric (DTG). It is noted that the differential thermogravimetric (DTG) dependence is a derivative of the TG-function. The optimum thermochemical parameters obtained during the high-temperature treatment of the test system allowed to reveal the nature of the destruction of thermally active components. The powder sample composition was identified by the morphologies of the thermal curves and the obtained numerical values of the intensities of endo- and exothermic effects, using the thermogravimetric readings of the TG lines associated with them. The analysis results were compared with the data given in the atlases of thermal curves of minerals and rocks, and compared with the descriptions of the thermal behavior of monomineral samples presented in reference sources and accumulated in the data bank of the laboratory of physical methods of analysis of the Institute of Metallurgy and Refinement of the National Academy of Sciences of the Republic of Kazakhstan, Almaty.

\section{Results and discussion}

\subsection{Discussion of the lead production slag analysis results}


Pursuant to the X-ray diffractometric slag sample analysis results, the formation of the following useful components was revealed: copper in the form of sulfides, complex compounds of oxides of lead, zinc, iron and copper, which are in the form of inclusions in an amorphous host matrix of complex composition. The lead production slag laboratory study results showed a fairly high content of non-ferrous metal compounds. This allows to state that the process for their extraction and disposal of toxic waste of lead production is technically and economically feasible. The research results are shown in Figure 1.

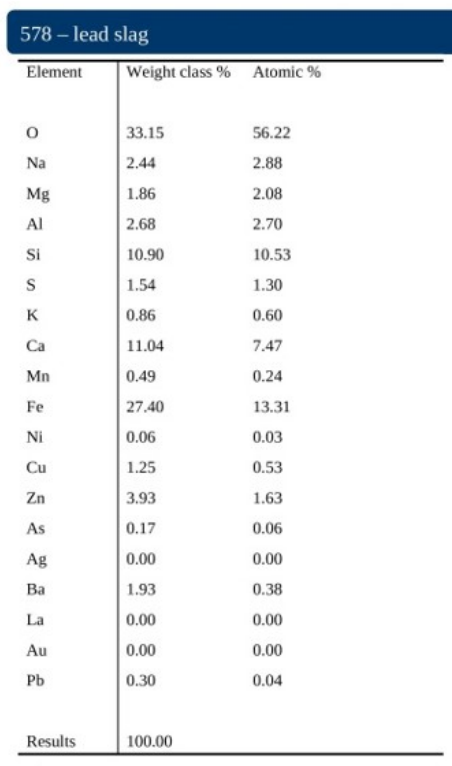

a)
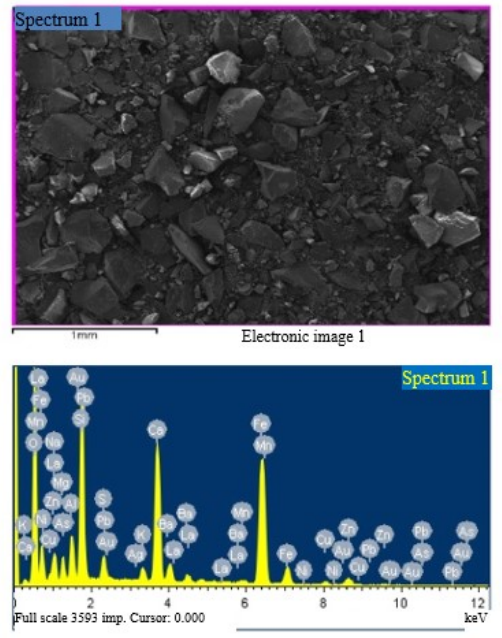

b)

Fig. 1. Scanning electron microscopy and X-ray microanalysis of lead-containing slag; a) the quantitative content of elements; b) morphological-qualitative analysis

The chemical method of analysis, as well as the results of X-ray fluorescence analysis of the slag, shows that the average content of toxic metals in the slags of lead production is in $(\%, \%)$ : lead - 2.38; zinc - 9.81 ; copper - 0.97 ; iron - 25.31 ; silicon oxide - 24.62 ; calcium oxide - 16.21; potassium oxide - 1.42; sulfur - 1.35 and moisture up to $3 \%$ of the total sample weights, the data of which are given in table 1.

Table 1. The content of the components of the lead production slag, formed during the raw material processing

\begin{tabular}{|c|c|c|c|c|c|c|c|c|}
\hline \multirow{2}{*}{ Sample No. } & \multicolumn{7}{|c|}{ Content of components, $\%$} \\
\cline { 2 - 10 } & $\mathrm{Pb}$ & $\mathrm{Zn}$ & $\mathrm{Cu}$ & $\mathrm{Fe}$ & $\mathrm{SiO}_{2}$ & $\mathrm{CaO}$ & $\mathrm{K}_{2} \mathrm{O}$. & $\mathrm{S}$ \\
\hline 1 & 2.0 & 9.6 & 1.1 & 26.1 & 25.4 & 14.0 & 1.2 & 1.3 \\
\hline 2 & 2.1 & 9.4 & 1.0 & 26.0 & 18.3 & 15.2 & 1.0 & 1.2 \\
\hline 3 & 2.2 & 9.6 & 0.92 & 25.0 & 20.2 & 16.4 & 1.2 & 1.18 \\
\hline 4 & 2.5 & 9.7 & 0.96 & 25.3 & 25.2 & 16.37 & 1.4 & 1.7 \\
\hline 5 & 2.55 & 9.8 & 0.98 & 30.6 & 24.9 & 16.4 & 1.8 & 1.52 \\
\hline 6 & 2.6 & 11.2 & 0.9 & 28.9 & 24.2 & 16.2 & 1.68 & 1.36 \\
\hline 7 & 2.7 & 9.6 & 0.93 & 25.1 & 25.4 & 16.35 & 1.75 & 1.52 \\
\hline average value & 2.38 & 9.84 & 0.97 & 26.71 & 24.62 & 16.21 & 1.42 & 1.35 \\
\hline
\end{tabular}

The analysis of Table 1 in terms of the indicators of the components indicates that the content of lead and zinc, as the main elements of non-ferrous metals, ranges (in\%) for lead within 2-2.7, and for zinc - within 9.5-11.3, which allows to extract them into target 
products, and the rest of the components can be used in the production of mineral fertilizers as trace elements or in the production of stone products.

A slag sample in dynamic heating mode on (DTA-, DTG- and TG-) curves in different temperature ranges left a series of effects caused by endo- and exothermic reactions, which are shown in Figure 2, and their quantitative values are shown in Table 2.

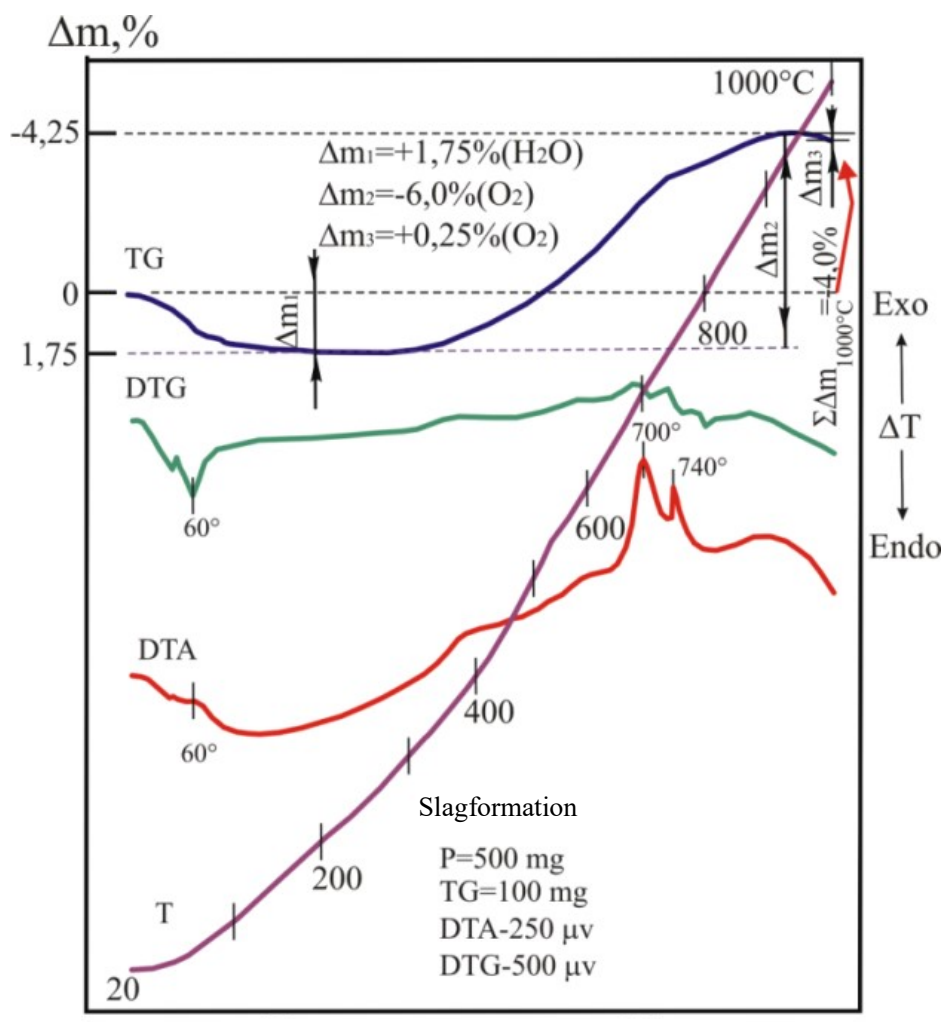

Temperature

Fig. 2.Derivatogram of a lead-containing slag sample

Table 2. Sequence of the volatile component weight loss quantitative values

\begin{tabular}{|c|c|c|c|}
\hline Weight loss sequence & Weight loss, $\%$ & Volatile components & $\begin{array}{c}\text { Decomposition } \\
\text { temperature interval, }{ }^{\circ} \mathrm{C}\end{array}$ \\
\hline$\Delta \mathrm{m}_{1}$ & 1.75 & $\mathrm{H}_{2} \mathrm{O}$ & $20-200$ \\
\hline$\Delta \mathrm{m}_{2}$ & -6.0 & $-\mathrm{O}_{2}$ & $280-930$ \\
\hline$\Delta \mathrm{m}_{3}$ & 0.25 & $\mathrm{O}_{2}$ & $930-1000$ \\
\hline$\Delta \mathrm{m}_{1000^{\circ} \mathrm{C}}$ & 4.0 & $\mathrm{H}_{2} \mathrm{O},-\mathrm{O}_{2}, \mathrm{O}_{2}$ & $20-1000$ \\
\hline
\end{tabular}

Note: in Figure 2 and Table 3, the minus (-) sign at the $\Delta \mathrm{m}_{2}$ value means the introduction of atmospheric oxygen into the system. This sign is the opposite of the sign applied to the weight loss parameter.

In the intervals of low temperatures of $20-200{ }^{\circ} \mathrm{C}(293-473 \mathrm{~K})$, an endothermic effect with a weight loss $\Delta \mathrm{m}_{1}$ equal to $1.75 \%$ of the sample weight is noted in the system under study, as shown in Figure 2 and Table 2. Many powder samples contain surface water, which is removed to the atmosphere within the specified temperature range. In this case, the main part of the evaporated molecular water can be attributed to the dehydration of particles of powder slag adsorbed by $\mathrm{H}_{2} \mathrm{O}$. After the sample dehydration process, the 
enthalpy of the system, in the range of $200-280{ }^{\circ} \mathrm{C}(473-553 \mathrm{~K})$, practically does not change, which is caused by the absence of weight loss. It should be noted that in the range of $280-930{ }^{\circ} \mathrm{C}(553-1203 \mathrm{~K})$, the thermogravimetric curve (TG) is steadily shifting upwards - towards an increase in the sample mass, which is caused by the introduction of atmospheric oxygen into the system and the formation of oxides of a new transformation. The increase in mass is accompanied by a rise in the DTA-curve line, which, within 640$800{ }^{\circ} \mathrm{C}(913-1073 \mathrm{~K})$, recorded clearly visible exothermic peaks at $700(973 \mathrm{~K})$ and $740{ }^{\circ} \mathrm{C}$ $(1013 \mathrm{~K})$. The processes that caused the introduction of heat into the system are associated with the oxidation of the ferrous components of the sample. Oxygen-enriched iron oxides are usually formed within the indicated temperature ranges. These high temperature peaks are caused by the transition of iron oxide from a lower acidity level to a higher level. At a higher temperature of $930{ }^{\circ} \mathrm{C}(1203 \mathrm{~K})$, the increase in sample mass reaches its limit $(\Delta \mathrm{m} 2$ $=-6 \%$ ). Further heating of the sample to $1000{ }^{\circ} \mathrm{C}(1273 \mathrm{~K})$ leads to a decrease in its weight by $0.25 \%$.

Thus, based on the results of differential thermal analysis, it is possible to select the main optimal temperature-time modes of the process of roasting and extraction of lead and zinc, as well as the technological design of the synthesis of non-ferrous metals from technogenic waste of lead production.

\subsection{Selection of technology}

As stated above, the main waste products of JSCYuzhpolimetall are calcium arsenate and granulated slag. Calcium arsenate is a lead production by-product. It is a mixture of basic calcium salts of orthoarsenic acid. Calcium arsenate is removed and stored in a specialized secure landfill, since it is the hazard class II products. Granulated dump slag is the end product of lead production and after granulation with granulating water is fed into sump, and then sent to the dump by motor transport. Dust, which is also a waste, is generated in the production of sinter during the electric cleaning of sulfur dioxide sintering machines in dry electrostatic precipitators of the dust and gas collection shop. Lead dusts are fire and explosive and are classified as hazard class 1 substances.

Based on the chemical composition of slag waste, a technology for selective extraction of lead and zinc compounds was selected. Scientists have been working on the problem of selecting and developing a technology for extracting non-ferrous metals from lead-zinc production for more than one year. This problem is due to the fact that since the rich deposits of non-ferrous metals were exhausted, the state's economic development required more and more consumption of non-ferrous metals. In the process of research and industrial testing, we have modernized the traditional technology for the selective extraction of lead and zinc compounds, that is, the well-known [16-25] technological processes for processing lead-containing slag by the Waelz method and refining using the Waelz kiln were reconstructed: the slag was fed from two ends (cold and hot) Waelz kiln. For the recovery of lead and zinc from lead slag, a Waelz kiln sublimation process has been developed. In the process of blowing a mixture of slag and coke, it is bubbling, the resulting gases, together with metal vapors, are sent to the dust collection stage, where sublimates are captured in a dust collection chamber, cooler and sleeve filters. Purified gases after dust and gas cleaning systems are released into the atmosphere.

To obtain lead oxide and zinc, slag and coal and limestone are fed into the component supply zone. At the same time, high-pressure compressed air is fed into the Waelz kiln. In the course of chemical reactions, lead-zinc slag sublimes to the formation of lead oxide and zinc by blowing in a certain amount of a mixture of pulverized slag and carbon-containing material from the hot end of the rotating Waelz kiln. The carbon-containing material plays the role of a reducing agent and volatilizes as $\mathrm{CO}_{2}$ during oxidation. And in the form of 
residues, technogenic mineral formations are formed with the content of silicon, calcium and iron.

After the release of gaseous lead and zinc, the gas flow is directed to the cooling pipes, where the main reaction takes place:

$\mathrm{PbO}+\mathrm{CO}=\mathrm{Pb}+\mathrm{CO}_{2}(1)$

$\mathrm{ZnO}+\mathrm{CO}=\mathrm{Zn}+\mathrm{CO}_{2}(2)$

Pursuant to Figure 3, the technological process of the toxic metal extraction method consists in the following: hot slag (1), class less than $10 \mathrm{~mm}$, by means of a belt conveyor (2) is fed simultaneously with coal (4) of class less than $10 \mathrm{~mm}$, which by means of a belt conveyor (4) is fed in certain ratios to the mixing process (5) of hot slag with coal. The mixed mixture is sent to the Waelz kiln (7), where compressed air containing a mixture of pulverized raw materials from slag dust and carbonaceous material of class less $1 \mathrm{~mm}(6)$ is blown. In the Waelz kiln, the process of sublimation of lead oxide and zinc takes place under the influence of high temperature. Carbon of carbon-containing material, fines of coal, metallurgical coke, etc., used in the technological process as a reducing agent leads to the formation of lead, zinc and carbon dioxide. Lead and zinc are then oxidized pursuant to the reaction $\mathrm{PPb}+\mathrm{O}_{2}=\mathrm{PbO}, \mathrm{Zn}+\mathrm{O}_{2}=\mathrm{ZnO}$ and re-enters the dust collection chamber.

Then the exhaust gases are fed to the cooling process, where zinc oxide and lead dust is cooled in the cooling chimney (9-10). The smoke temperature after cooling the system is reduced to $150{ }^{\circ} \mathrm{C}$. The smoke, passing through the sleeve filter, completely traps zinc oxide and lead dust. The dust cleaning system efficiency is $99.8 \%$. Lead and zinc oxide collected in a sleeve filter are fed into big bags (11-12). Furnace gas containing such harmful gases as sulfur dioxide is subjected to a double alkalization process pursuant to the reaction:

$$
\begin{aligned}
& \mathrm{NaHCO}_{3}+\mathrm{SO}_{2} \rightarrow \mathrm{NaHSO}_{3}+\mathrm{CO}_{2} \\
& \mathrm{CaO}+\mathrm{NaHSO}_{3}+\mathrm{O}_{2}+\mathrm{CO}_{2} \rightarrow \mathrm{CaSO}_{4} \cdot 2 \mathrm{H}_{2} \mathrm{O}+\mathrm{NaHCO}_{3}
\end{aligned}
$$

The sulfur dioxide absorption efficiency is about $95 \%$.

For a more complete and efficient recovery of lead and zinc from man-made slags of lead production, sublimation processes have been developed in traditional rotary drum kilns (Waelz kilns) by blowing in the dust of a class less than $0.1 \mathrm{~mm}$ and the process of bubbling a mixture of slag and coke with a fraction of $0-5 \mathrm{~mm}$. Together with metal vapors, the gases that are formed during this process are sent to dust collection. Sublimates are captured in a dust collector, a cooling chamber and sleeve filters, and the treated gases are discharged into the atmosphere (13), as shown in Figure 3. 
Fig. 3. Technological scheme of the toxic metal extraction method

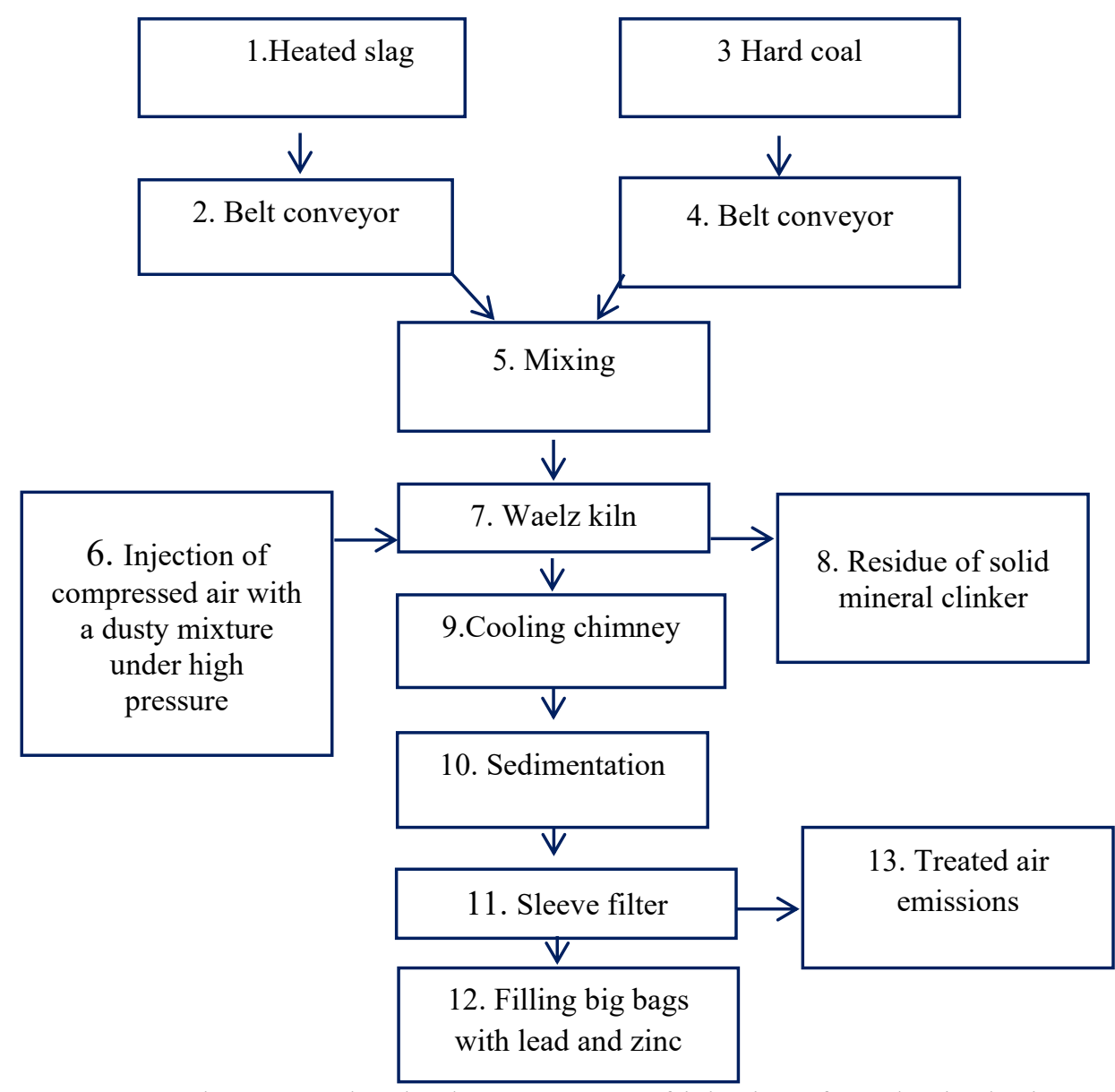

Pursuant to the proposed technology, a system of injection of a pulverized mixture of lead slag and coke or pulverized coal of less than $1 \mathrm{~mm}$ class from the hot end of the kiln is used, and the bulk of the initial charge components of less than $10 \mathrm{~mm}$ class is fed from the cold feed end. This considers the peculiarities of the kiln operation and the synthesis of non-ferrous metals, enhances the recovery rate and production efficiency of lead and zinc oxides. The proposed technology is distinguished by the use of lead production slag fed into a rotary drum kiln in two oppositely directed flows. The dispersion of the composition is less than $10 \mathrm{~mm}$, containing slag, coke fines and internal overburden of coal mining from the cold end of the rotary drum kiln and the pulverized part with a dispersion of up to $1 \mathrm{~mm}$ together with a carbon-containing material with a dispersion of up to $1 \mathrm{~mm}$ from the hot end of the rotary kiln allow to intensify the synthesis of zinc and lead oxides and reduce energy consumption by up to $10-15 \%$. The proposed technology utilizes the lead production slag, which is a sintered granular form material with a size ranging within 2-6 mm, containing a small amount of slag up to $10 \mathrm{~mm}$ in size, with a bulk density of about $2 \mathrm{t} / \mathrm{M}^{3}$ and an angle of repose of 35 degrees.In addition to lead slag, the technological line utilizes the carbon-containing material, the chemical composition of which is shown in Table 3.In order to increase the environmental and economic efficiency of the technology, we propose feeding a mixture of pulverized slag material into the Waelz kiln from the hot end and 
pulverized carbon-containing materials from the hot end of the kiln, and the bulk of the initial charge components from the cold feed end.

Table 3. Carbon-containing material chemical composition

\begin{tabular}{|c|c|c|c|c|c|c|}
\hline \multicolumn{7}{|c|}{ Component content (\%,\%) } \\
\hline Material name & $\mathrm{C}$ free & $\mathrm{SiO}_{2}$ & $\mathrm{Al}_{2} \mathrm{O}_{3}$ & $\mathrm{Fe}_{2} \mathrm{O}_{3}$ & $S_{\text {общ. }}$ & Moisture \\
\hline $\begin{array}{c}\text { Coal mining } \\
\text { screening }\end{array}$ & $35-65$ & $27-32$ & $2.5-6.5$ & $2.6-2.9$ & $\begin{array}{c}\text { up to } \\
0,01\end{array}$ & up to 0,01 \\
\hline Coke fines & 85 & $2-4$ & $2-3$ & $1-2$ & $\begin{array}{c}\text { up to } \\
0,01\end{array}$ & up to 0,01 \\
\hline
\end{tabular}

The lead oxide, zinc oxide and copper concentrate are produced by feeding slag from lead production and coke into the Waelz kiln, while high pressure compressed air is fed into the Waelz kiln. This process gives a reaction: lead-zinc slag sublimes to form lead oxide and zinc, coal is burned and volatilized as $\mathrm{CO}_{2}$. The remainder contains a technogenic mineral formation containing silicon, calcium and iron. After the metallic lead, zinc and copper volatilization, the gas flow is directed to cooling and sedimentation of the separated lead, zinc and copper oxide dust.

To reduce the level of impact on the environment, before being discharged into the atmosphere through a high-rise stack, the gases removed from the Waelz kiln go through a successive stage of dry and wet cleaning.

Construction of a processing lead slag plant will provide for:

- the mitigation of the impact of the dumps (waste heaps) (the historical formations) on the environment;

- the exclusion of the irrational use of lands occupied by slag dumps;

- the partial satisfaction of the market demand for raw materials for the production of non-ferrous metals: lead, zinc and copper

The proposed safe technology for the disposal of lead-containing slag waste by extracting toxic metals eliminates local pollution and the potential impact on the safety of historical lead slag, as well as eliminates the long-term occupation of large amounts of land with this slag and ensures the implementation of a circular green economy.

\section{Conclusion}

1. The results of thermal, X-ray fluorescence semi-quantitative analyzes, scanning electron microscopy and X-ray microanalysis of lead slag showed that the lead production slag contains toxic metals that are dangerous sources of environmental pollution;

2 . It has been determined that the average content of toxic metals in slags formed during the raw material processing is: lead - 2. 38; zinc -9.81 ; copper -0.97 ; iron -25.31 ; silicon oxide -24.62 ; calcium oxide -16.21 ; potassium oxide -1.42 ; sulfurs $-1.35 \%$ of the total weight of test;

3. The results of chemical analysis showed that the composition of lead production slag contains a sufficiently high amount of non-ferrous metal compounds: the qualitative composition and content of non-ferrous metals in lead slags allows to make the process of utilization of toxic waste from lead production technically and economically feasible;

4. A new technology for a more complete and selective extraction of lead and zinc oxides from slag waste of lead production has been developed;

5. Application of the proposed technology allows to reduce the fuel and energy costs while reducing the amount of dust and gas emissions by $10-15 \%$;

6 . The use of a new technology for the selective method of extracting non-ferrous metals will improve the ecological state of the environment and reduce the negative impact on human health through the disposal of toxic slags from lead production; 
7. The developed technology allows to efficiently process waste man-made slags of lead production with the production of lead and zinc oxides, as well as for the production of mineral fertilizers containing microelements and as building materials. Herewith, a significant contribution is made to the development of a system for the rational use of natural and secondary resources.

\section{References}

1. Whowill rid Shymkent of 2 million tons of lead sludge?,https://otyrar.kz/

2. Methodological guidelines for calculating emissions (emissions) of pollutants into the atmosphere during mechanical processing of metals (in terms of specific emissions) RND 211.2.02.06-2004. Approved by order of the Minister of Environmental Protection dated 20.12.2004. No. 328-r.

3. S.Yu.Yusfin, L.I.Leontyev, P.I.Chernousov, Industry and environment, 469 (2009)

4. A.V. Tarasov, A.D. Besser, V.I. Maltsev, V.S. Sorokina, Metallurgical processing of secondary lead material, 224 (2003)

5. Technological regulations "Construction of a metallurgical plant for the production of zinc oxide, lead oxide and copper concentrate at the address Ordabasy district, Badamsky rural district, 029 quarter, section 1563, Turkestan region, cadaster 19-293023-1563", license No. 17010101 dated 05.06.2017

6. Hygienic standards for atmospheric air in urban and rural areas, approved by order of the Minister of National Economy of the Republic of Kazakhstan No. 168 dated February 28, 2015

7. Sanitary Rules "Sanitary and Epidemiological Requirements for Establishing a Sanitary Protection Zone of Production Facilities", approved by order of the Minister of National Economy of the Republic of Kazakhstan dated March 20, 2015 No. 237

8. GOST 17.2.3.02-78 Nature protection. Atmosphere. Regulations for establishing permissible emissions of noxious pollutants from industrial enterprises.

9. GOST 17.2.301-86 Nature protection.

10. GOST 17.2.1.01-76 Nature protection. Atmosphere. Classification of emissions by composition.

11. Lead waste water treatment, https://ru-ecology.info/

12. N.F.Izmerov, Lead and health. Hygienic and medical-and-biological monitoring, 256 (2000)

13. Ye.O. Muradova. Life safety (2006)

14. M. Duisebaev, Zh. Rakhmanberdieva, B. Amiraliev,Poisk, 3 (1), 37 (2010)

15. M.K.Dyusebaev, R.K.Niyazbekova, D.M.Zhantasova, Zh.N.Rakhmanberdieva, M.E.Tolegen, Bulletin of the Almaty University of Energy and Communications, $\mathbf{3} / \mathbf{2}$ (10), 62 (2010)

16. V.M. Garin, Industrial ecology (2005)

17. Sh.M.Moldabekov, K.T.Zhantasov, V.K.Bishimbaev, K.D.Aibalaeva, M.K.Zhantasov, Zh.M.Altybaev, Innovative patent No. 79381 - A method for producing complexmixed mineral fertilizers. Committee on Intellectual Property Rights of the Ministry of Justice of the Republic of Kazakhstan. Publ. on 07.11.2011 Bulletin No. 11 
18. K.T.Zhantasov, K.D.Aibalaeva, L.Kh.Frangulidi, M.R.Barlybaev, D.S.Berzhanov, B.N.Yurchenko, M.K.Zhantasov, Technological equipment for the production of yellow phosphorus, 444 (2014)

19. K.T.Zhantasov, Kh.T.Zhanov, G.A.Murzagaraev, N.A.Miroshnikov, Development of the technology for pelletizing phosphorite fines in a rotary kiln. Thesis report (1979)

20. K.T.Zhantasov, N.A.Mironov, V.A.Ershov, A.M.Kunaev, O.T.Tyumbaev et al. Industrial tests of the pelletizing of phosphate-siliceous fines in a rotary kiln (1981)

21. N.A. Miroshnikov, E.U. Zhumartbaev, A.M. Kunaev, K.T. Zhantasov, O.T. Tyumbaev Chemical Raw Materials Research Committee, 1, 48 (1993)

22. K.T.Zhantasov, Development and implementation of low-waste and energy-saving technologies in the production of yellow phosphorus: Abstract of a thesis for a doctorate in technical sciences: 05.17.01 - Technology of inorganic substances.Shymkent,45 (1998)

23. K.T.Zhantasov, Series of chemical technology and environmental engineering, 92 (1996)

24. M.Mäkelä, I.Välimäki, R.Pöykiö, H.Nurmesniemi, O.Dahl, Int. J. Environ. Sci. Technol. (2013)

25. Z.Youcai, Z.Chenglong, Pollution Control and Resource Reuse for Alkaline Hydrometallurgy of Amphoteric Metal Hazardous Wastes, 18 